\title{
CENTRAL EUROPEAN PRODUCTION SUCCESSES (PAST TWO DECADE) AND OUR ANTICIPATION OF RESEARCH AND DEVELOPMENT SUCCESS FOR THE AUTOMOTIVE INDUSTRY TODAY (NEXT ONE DECADE)
}

\author{
Ján Lešinský \\ Slovenská Technická Univerzita (STU) v Bratislave \\ Strojnicka fakulta \\ Námestie slobody 17, 81231 Bratislava, Slovakia \\ tel.: +421905245214, +421257296306 \\ e-mail:jan.lesinsky@stuba.sk
}

\begin{abstract}
The automotive industry (AI) and specifically the automotive suppliers area is one of the fastest developing sector in CE countries (CEC). Given the world-top class supply base, high intellectual capital and ability to readily achieve European levels of productivity, the central part of continent can more competitively satisfy the needs of customers than at any other period of time in Europe. Increase of passenger cars production (2005 2012) in $500 \mathrm{~km}$ radius area from 1,9 to 5,2 mil., new technology solutions, TALENT and TOLERANCE by human assets, are very important influences and expectations from combination of traditional and V4 countries in this period. CE countries can offer all logistic optimisation, productivity and added value increases. Particular remarks are also analysed: necessity for co-operation by regions and continents in the standards area, the weight of CEC in the global automotive production (1991 - 2011), some influences of human resources on production system innovation, strategy of producers from Europe, Asia, North America in our continent and suppliers in Central Europe countries, $R \& D$ and human resources life long learning system for AI in the future.
\end{abstract}

Keywords: strategy of producer, automotive, supplier's network, $R \& D$

\section{Introduction}

Automotive Industry was a key attraction in Foreign Direct Investment (FDI) for 20 years of changing the situation of all V4 countries in and out of them. Not only the Central European Countries - Czech Republic, Hungary, Slovak Republic and Poland (V4) but also Romania and Slovenia can more competitively satisfy the needs of West European, Asia and North America producers from automotive industry - final producers and suppliers companies, too. In the V4 countries in the last 20 years there were renovated or new established 36 plants for final car or engines production (!) and some thousand suppliers new or joint venture plants.

Positives: Material and energy choice criteria are for automotive more stringent "mechanical culture" of corrosive industry was successfully changed. Consumer demands, technical and environmental constraints forced the automotive area to work with excellent technology... human resources and their creativity increased. From 1992 to 2011 the production in the automotive sector increased over 4 times in numbers of units (referring to V4 and SLO, ROM), revenue of the sector (together with suppliers production for in and out of these countries), too. The potential of V4 countries is for next $20 \%$ in the increase in outputs and potential of human resources for automotive and related production viewpoint $30-50 \%$ mainly for research and development. 

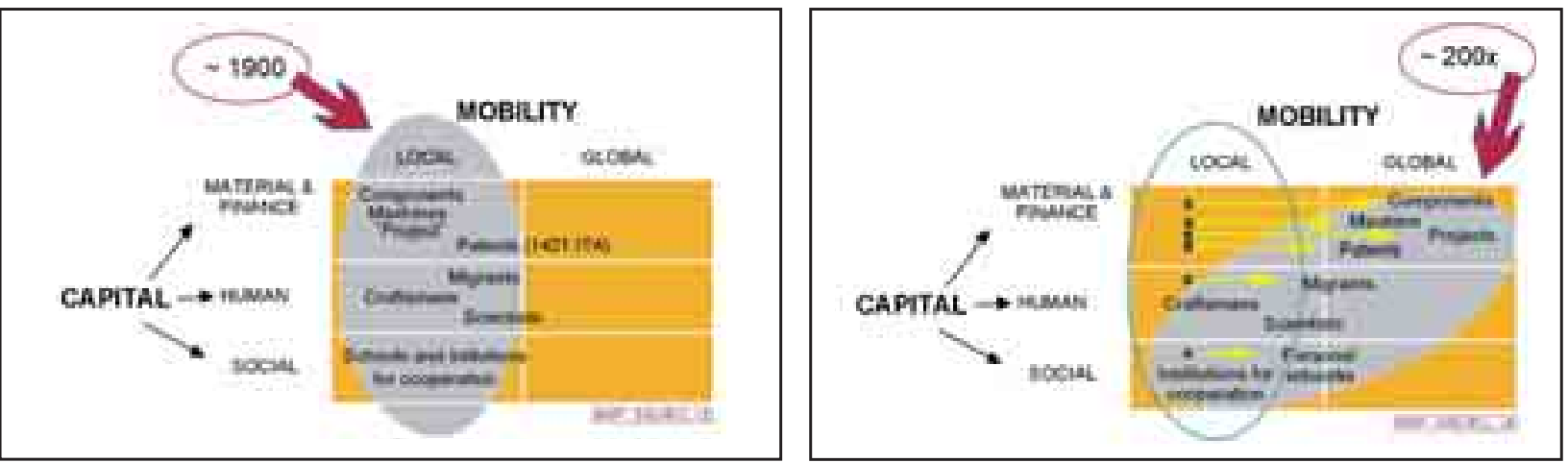

Fig. 1. Movement of resources (capital) - globalisation - last century - $1900-2000$

\section{Last stages and future ones}

In 1991-2000 CEC was named as a transition process area - privatisation and steps from piece production to mass production of many products. In 2001 -2010 there were clearing up questions (in CEC's) from P.E.S.T.L.E. (political, economical, social, technological, legal, ecological) conditions and factors for investors which started a massive progress of supplier network improvement (by OEM's) area - $100 \mathrm{~km}$ distance for JIT delivery, $500 \mathrm{~km}$ area for systems and modules delivery, with positive influence - in 12 countries now are 20 plants for car assembly, and shortening of production cycle 5-6 years for new car type. Also the V4 countries membership in the EU and Slovakia in Euro zone were positive signals.

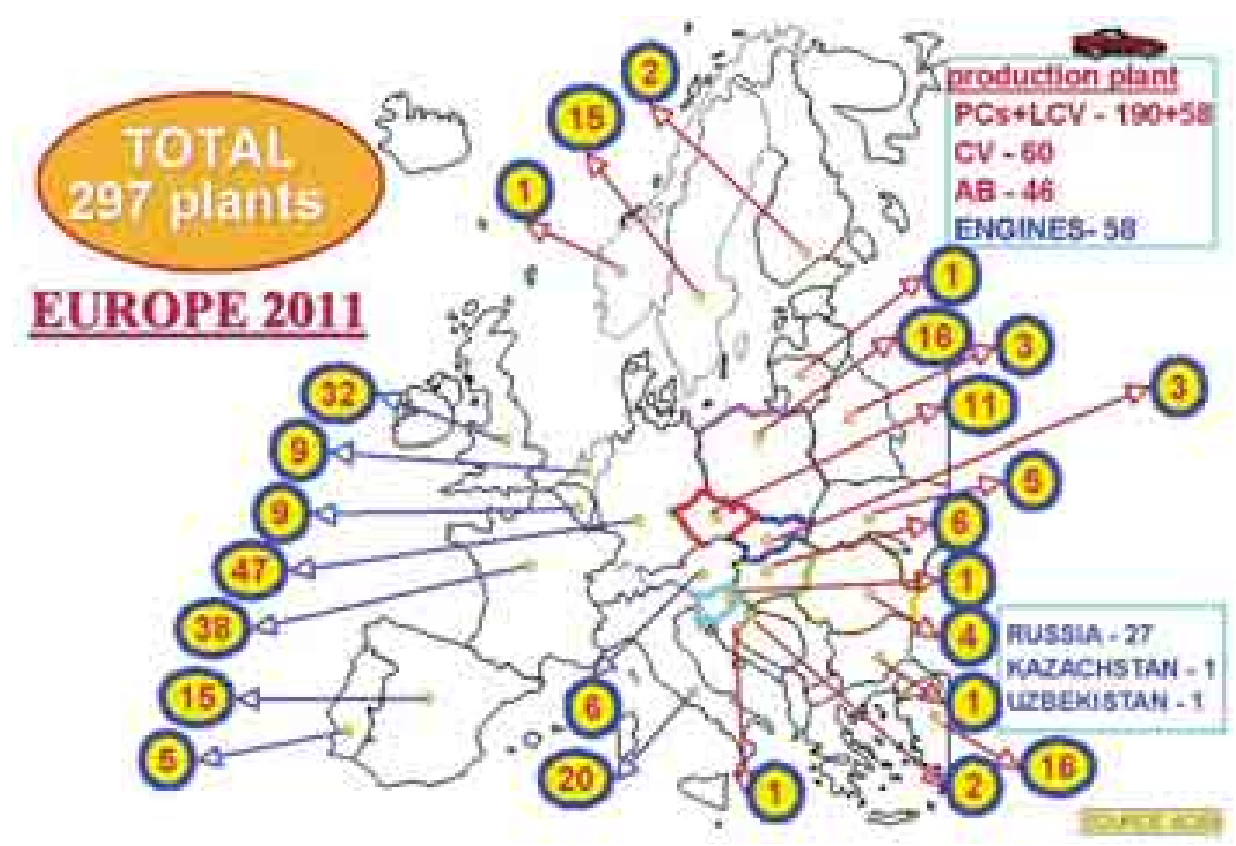

Fig. 2. Spacing of production plants - vehicles and engines - automotive industry-Europe-end of decade

These years - 2011-2020 can be in the CEC characterized:

a) The opportunities for ever better performance are very good - new technology,

b) Large volume suppliers in machinery and support industry (electro, chemistry, oil, plastics),

a. For world wide customers,

b. With the latest technology,

c) standardised producers,

d) positive environment,

e) small dependence on additional import, 
a. good row materials and energy base potential,

b. high quality of steel, aluminium, plastics, composites, fuel production, glass,

f) in human resources,

a. labour flexibility and skills,

b. price of work - by good innovation potential for new productive plants,

c. perspective young generation for $R \& D$,

d. experience, practice and contacts (Central Europe as a bridge for W-E cooperation).

All (and other per region) these factors fill up a positive situation for residential settlement of new products and technologies with application of (in an area) developed materials... and with new products are coming suppliers also with R\&D (share of R\&D in 2000 was $30 \%$ of value creation by suppliers, to 2020 and after the trend can be over $60 \%$ ).

\section{Characteristics of the decade 2021-2030}

The increase of R\&D by suppliers - there are connected with modules, systems and car production and assembly very close- they are for the CEC (mainly V4, but also for SLO, ROM) in the continental selection of labour very important.

a) production of premium cars, small and middle cars and hybrid and electro cars can be main European area here ( together with R\&D centre for HQ of mainly WE producers),

b) networks of highways and railways are convenient for big logistic profits - minerals, materials, energy...

c) complexity of car electronic devices - finished,

d) big increase in the volume of money for R\&D ( to be equal to production \& sale money),

e) increase in TIER_0.5, decrease of No. TIER_1 and_2 (complexity of supply), and

f) big increase of Asia investments in Europe.

All these factors need an urgent start of cooperation.

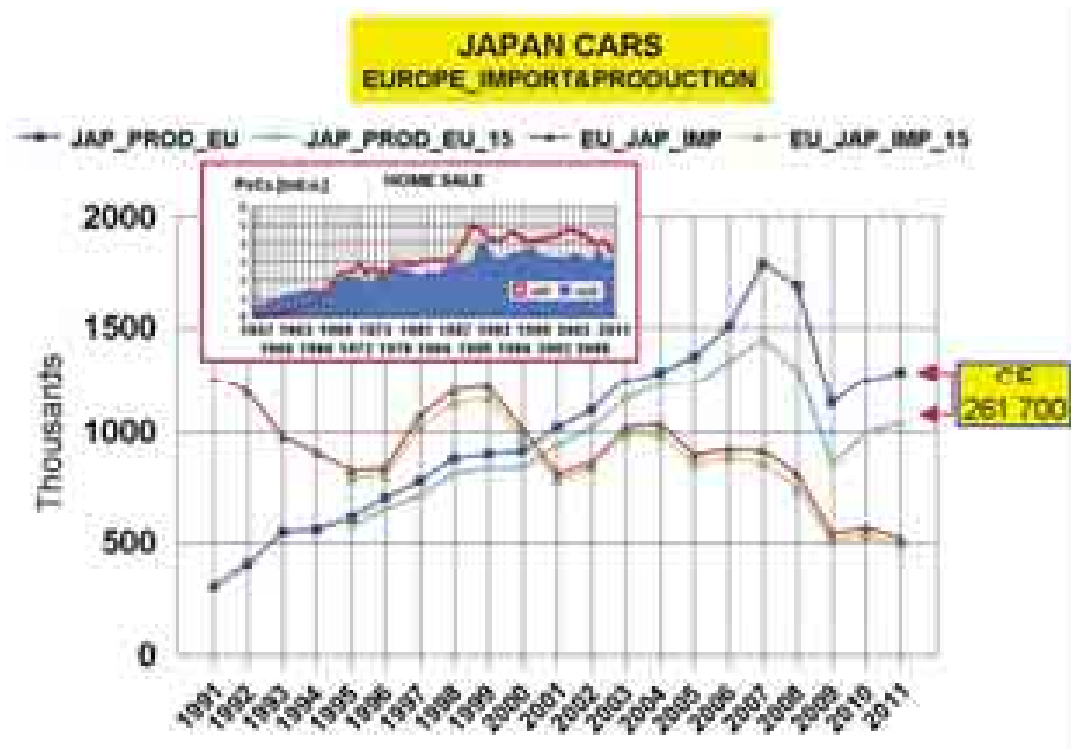

Fig. 3. Production and import of Japan brands in/to Europe [thousands units/year]. Comparison with home Japan/Germany sale (small window) - [Source: JAMA]

\section{Conclusions}

Sixty years ago the automotive evolution in Europe was started. Global dependence of players in the automotive production increased. Price of materials and energy for production and price of oil products, price of cars and spare parts together with infrastructure, recycling and fill up the 
emission norms, influencing and conditioning future of transport means. In this and next decade we are expecting an increase of money share for $\mathrm{R} \& \mathrm{D}$, for human resources education and more work for engineers in the services for automotive industry $(R \& D$, Information and communication technology, safety of information, design, shortening of production cycles, new materials and production ...).

\section{Acknowledgements}

This work was supported by the Agency for SF EU, project "Industrial research method and processes of generative design and knowledge engineering for car development" under the contract No. 26240220076 (OPVaV-2011/4.2/07 - SORO).

\section{References}

[1] Lešinský, J., Auto Mobility 2000 to 2020. Production and Transport in Central Europe, Journal of Mechanical Engineering, No. 47, Vol. 12, pp. 687-702, UDC 629.3, Ljubljana.

[2] Lešinský, J., Auto - Industry in the CEE Countries. Reality and the Future, Journal of KONES Powertrain and Transport, Vol. 10, No. 1-2, pp. 149-153, Warszawa 2003.

[3] Lešinský, J., Conditions for Automotive Industry Suppliers Network Development in the $C E E C$, Lecture on Panel Discussion: High-performance collaborative communities OEM Suppliers expectations with respect to purchasing policy, EAEC Congress, SIA, Paris 2003.

[4] Lešinský, J., Europe Countries Automotive - Auto-mobility and co-operation, Pilot lecture for Panel: IPEASI - Forum on Integration Processes in European Automotive \& Supply Industry, Proceedings of 10th European Automotive Congress EAEC, EAEC05YU-1P01, YUMV, p. 6, Beograd 2005.

[5] Lešinský, J., Central European automotive production and innovation factor for global systems, 11th European Automotive Congress, Scientific Society of Mechanical Engineers, Budapest, Hungary 2007.

[6] Šikula, M., Lešinský, J., Strategy of Development of Slovak Society (slovak), 589 pages. Institute of Economy of Slovak Academy of Sciences-SAV, Bratislava.VEDA, Bratislava 2010.

[7] Focus Reports: Booming Central Europe..., Ward's Autoworld, Vol. 12, Is. 12, pp. 22-29, Prism Bussiness Media Inc., Kansas 2007.

[8] Lešinský, J., Present State and Future of Cars production in Slovak Republic, Document No. XII-1879-06, International Institute of Welding, Commission XII - Arc welding, Bratislava 2006. 